http:/ / dx.doi.org/10.5597/lajam00154

\title{
NATURAl History OF DOLPHINS OF THE GENUS Sotalia
}

\author{
Fernando C. W. Rosas ${ }^{1, *}$, Juliana Marigo ${ }^{2}$, Maira Laeta ${ }^{3,4}$ and Marcos R. Rossi-Santos ${ }^{5}$
}

\begin{abstract}
Aвstract: General biology, including food habits, reproduction, age and health of the dolphins of the genus Sotalia, are reviewed according to current scientific knowledge. At least 25 teleost fish families, 5 cephalopod families and 1 crustacean family are included in the diet of the Guiana dolphin (S. guianensis), while up to 13 fish families were identified in the stomachs of the tucuxi (S. fluviatilis). Among the fish consumed by Sotalia spp., the schooling fish are the most common ones and both dolphin species use similar foraging strategies. However, due to the completely different ecosystems used by them, prey species consumed by these dolphins are also different. The maximum age of incidentally caught Guiana dolphin was 30yr and the maximum age estimated in the tucuxi was $43 y \mathrm{r}$. The maximum total body length and weight reached by S. guianensis was $222 \mathrm{~cm}$ and $121 \mathrm{~kg}$, respectively, and for $S$. fluviatilis $152 \mathrm{~cm}$ and $53 \mathrm{~kg}$, respectively. Sexual maturity in the Guiana dolphin was estimated to occur at 170-180 cm in males, and 160-169 cm in females, while onset maturity in the tucuxi occurs at around $140 \mathrm{~cm}$ in males and $132-137 \mathrm{~cm}$ in females. Ovulation apparently occurs only in the left ovary of the tucuxi, while both ovaries of the Guiana dolphins are functional. The proportion of testes mass in relation to total body mass in adult males can reach up to $5 \%$ in the tucuxi, and 3.3\% in the Guiana dolphin, suggesting a promiscuous mating system with sperm competition in both species. Although seasonal birth peaks can occur in Guiana dolphins, they seem to reproduce throughout the year. However, the tucuxi presents defined birth seasonality, with most females giving birth during the low-water season in the Amazon. We suggest maintaining S. fluviatilis in the 'Data Deficient' category of the IUCN Red Data Book. Nevertheless, due to the recent recognition of S. guianensis as a species, its conservation status has not been assessed yet. This species, however, deserves special attention as it is strongly subjected to anthropogenic pressures throughout its distribution.
\end{abstract}

Resumo: Aspectos da biologia geral, incluindo hábitos alimentares, reprodução, idade e saúde dos golfinhos do gênero Sotalia foram revisados de acordo com o conhecimento científico atual. Pelo menos 25 famílias de peixes teleósteos, 5 famílias de cefalópodes e 1 família de crustáceos foram identificadas na dieta do boto-cinza (S. guianensis), enquanto 13 famílias de peixes foram identificadas nos estômagos do tucuxi (S. fluviatilis). Ambas as espécies predam principalmente (mas não exclusivamente) sobre peixes formadores de cardume e utilizam estratégias de forrageio similares. No entanto, em função das diferenças nos ecossistemas em que ocorrem, as espécies de presas consumidas por estes golfinhos são totalmente diferentes. A idade máxima de botos-cinza incidentalmente capturados foi 30 anos e a idade máxima estimada no tucuxi foi de 43 anos. O comprimento e peso máximos registrados para $S$. guianensis foram de $222 \mathrm{~cm}$ e $121 \mathrm{~kg}$, e para S. fluviatilis de $152 \mathrm{~cm}$ e $53 \mathrm{~kg}$, respectivamente. O comprimento de maturidade sexual no boto-cinza foi estimado em $170-180 \mathrm{~cm}$ nos machos e $160-169 \mathrm{~cm}$ nas fêmeas, enquanto que no tucuxi a maturidade ocorre em torno dos $140 \mathrm{~cm}$ nos machos e entre 132-137 cm nas fêmeas. A ovulação aparentemente ocorre apenas no ovário esquerdo no tucuxi, ao passo que ambos os ovários no boto-cinza são funcionais. A relação peso dos testículos/peso corporal de machos adultos pode alcançar 5\% no tucuxi e 3,3\% no boto-cinza, sugerindo um sistema reprodutivo promíscuo com competição de espermatozóides em ambas espécies. Embora picos de nascimento sazonais possam ocorrer em S. guianensis, a espécie parece se reproduzir o ano todo. No entanto, o tucuxi apresenta uma sazonalidade de nascimentos bem definida, com a maioria dos partos ocorrendo durante o período de nível baixo das águas dos rios da Amazônia. Em função das lacunas existentes em alguns aspectos da biologia do tucuxi, sugerese a manutenção de S. fluviatilis como 'insuficientemente conhecida' (DD). Por outro lado, em virtude do recente reconhecimento de S. guianensis como espécie, seu status de conservação ainda não foi avaliado. Esta espécie, no entanto, requer especial atenção em função da forte pressão antrópica a que está sujeita ao longo de toda a sua distribuição.

KEYwORDs: age, biology, feeding habits, health, reproduction, Sotalia fluviatilis, Sotalia guianensis.

\section{Introduction}

A three-dimensional morphometric analysis carried out on Sotalia skulls from the coastal and Amazonian regions revealed significant differences, separating the so-called marine and riverine ecotypes of Sotalia fluviatilis into two different species (Monteiro Filho et al., 2002). This was also supported by Cunha et al. (2005) and Caballero et al. (2007), who used the mitochondrial DNA control region and cytochrome- $b$ sequence, as well as nuclear intron
DNA sequences, showing that marine and riverine ecotypes form very divergent monophyletic groups. Therefore, the freshwater species, commonly known as tucuxi and distributed throughout the Amazon region (Gómez-Salazar et al., 2010 this volume), remained with the specific epithet Sotalia fluviatilis (Gervais and Deville in Gervais, 1853). However, the coastal species, which is distributed from Honduras $\left(15^{\circ} 58^{\prime} \mathrm{N}\right)$ in Central America (da Silva and Best, 1996) to Santa Catarina State $\left(27^{\circ} 35^{\prime}\right.$ S) (southern Brazil) in South America (Simões-Lopes, 1987) ${ }^{6}$,

\footnotetext{
${ }^{1}$ Lab. Mamíferos Aquáticos, Instituto Nacional de Pesquisas da Amazônia, C.P. 478, Manaus, AM, 69011-970, Brazil.

2 Projeto BioPesca, Rua Lorena 27, Ubatuba, SP, 11680-000, Brazil.

${ }^{3}$ Grupo de Estudos de Mamíferos Marinhos da Região dos Lagos.

${ }^{4}$ Departamento de Endemias Samuel Pessoa, Escola Nacional de Saúde Pública Sergio Arouca, FIOCRUZ, Rua Leopoldo Bulhões, 1480, Manguinhos, 21041-210, Rio de Janeiro, RJ, Brazil.

${ }^{5}$ Instituto Baleia-Jubarte, Rua Barão do Rio Branco, 26, Caravelas, BA, 45900-000, Brazil.

* Corresponding author, e-mail: frosas@inpa.gov.br.

${ }^{6}$ SIMÕEs-Lopes, P.C. (1987) Sobre a ampliação da distribuição do gênero Sotalia Gray 1886 (Cetacea: Delphinidae) para águas do Estado de Santa Catarina Brasil. Pages 87-88 in Proceedings II Reunião de Trabalho de Especialistas em Mamíferos Aquáticos da América do Sul. Rio de Janeiro, Brazil.
} 
is called Sotalia guianensis (Van Bénéden, 1864). In an attempt to associate the common name of the latter species with the geographic location where it was first described, Flore et al. (2010 this volume) recommended using Guiana dolphin as the vernacular name in English for S. guianensis, which was, therefore, adopted in this article.

Both species of the genus Sotalia were described in the $19^{\text {th }}$ century and despite having been regularly observed, very little was known about their biology until 25-30yr ago. Continuous and long-term studies of the freshwater species started in 1979 at the National Institute of Amazonian Research (INPA, Manaus, Brazil) (Magnusson et al., 1980; da Silva, 1983; Best and da Silva, 1984). Long-term studies of the Guiana dolphin (S. guianensis) are also very recent. Apart from sporadic records and very few studies on parasites and morphology (Lins de Almeida, 1933; Carvalho, 1961; 1963), the first studies on the biology and ecology of the species only started in the 1980s (Borobia, 1984; Geise, 1984).

The main purpose of this document is to describe the general aspects of the biology of both species of the genus Sotalia with emphasis on age, food habits, reproduction, and health, comparing these parameters considering both species.

\section{General Characteristics}

Dolphins of the genus Sotalia are dark gray on their dorsal region. There are two lateral blazes of lighter gray that run dorso-ventrally, one behind the flippers and one about mid-way down the body. Ventral coloration can vary from pink to very light gray (da Silva and Best, 1994; 1996; Caballero et al., 2007; Randi et al., 2008). The Guiana dolphin can reach up to $222 \mathrm{~cm}$ in total length (Barbosa and Barros, 2006) ${ }^{7}$ and $121 \mathrm{~kg}$ (Rosas and Monteiro Filho, 2002), while the maximum total length and weight recorded for the tucuxi are $152 \mathrm{~cm}$ and $53 \mathrm{~kg}$, respectively (da Silva and Best, 1994).

\section{AgE}

Among the different techniques used to estimate age in Sotalia spp., the thin-section method originally described by Hohn et al. (1989) for bottlenose dolphins presents better reading acuity in Guiana dolphins (Rosas et al., 2003; Santos et al., 2003; Ramos and Di Beneditto, 2005; Ramos et al., 2008). According to Rosas et al. (2003), there is one accessory layer (sometimes two) between the neonatal line and the Growth Layer Group (GLG) of the first year. There is some evidence that the alwayspresent accessory layer is attributed to weaning in this species. This hypothesis, however, still needs to be proved (Rosas et al., 2003). The maximum age estimated in Guiana dolphins incidentally caught in fishing nets was 30yr (Rosas et al., 2003; Di Beneditto and Ramos, 2004). On the other hand, the maximum number of GLGs counted in female and male tucuxi teeth was 43 and 26, respectively (da Silva, 1994). According to the latter author, the large variability in body lengths for different age groups makes the age prediction of tucuxis based on their body lengths unreliable. A similar observation was also made by Santos et al. (2003) concerning S. guianensis. According to Ramos et al. (2000) and Santos et al. (2003), the age of physical maturity in Guiana dolphins from southeastern Brazil is reached at $7 y$. However, Fettuccia (2001), after analyzing the fusion of vertebral epiphyses of Guiana dolphins from southern Brazil, estimated that the physical maturity of this species occurs after $12 \mathrm{yr}$ of age. To our knowledge, there are no physical maturity estimations for the tucuxi.

\section{FEEDING Habits}

At least 70 fish species consisting of 25 families are consumed by S. guianensis from the Brazilian coast (Borobia and Barros, 1989; Schmiegelow, 1990; Emerim, 1994; Reis et al., 1998\%; Di Beneditto, 2000; Zanelatto, 2001; Santos et al., 2002; Gurjão et al., 2003; Oliveira, 2003; Marcucci et al., 2004'; Barbosa and Barros, 2006; Di Beneditto and Siciliano, 2007; Oliveira et al., 2008) (Table 1 ). Cephalopod and crustacean species recorded in $S$. guianensis stomachs are presented in Table 2. Among the studies that analyzed more than 25 Guiana dolphin stomach contents, teleosts appeared with frequencies of occurrence between 91 to $100 \%$ of the stomachs analyzed, while cephalopods were recorded in frequencies varying from 40 to $74 \%$ (Di Beneditto, 2000; Zanelatto, 2001; Gurjão et al., 2003; Oliveira, 2003).

Despite being considered by most authors as a species with opportunistic feeding habits (Di Beneditto, 2000; Zanelatto, 2001; Santos et al., 2002; Oliveira, 2003; Gurjão et al., 2003), the trophic niche width of S. guianensis on the Paraná coast (southern Brazil), estimated using Levins' index (Krebs, 1989), was closer to the minimum

\footnotetext{
${ }^{7}$ Barbosa, L.A. And Barros, N.B. (2006) Aspectos da distribuição, biologia e captura acidental do boto-cinza (Sotalia guianensis) no litoral do Espírito Santo, Brasil. Page 47 in Siciliano, S., Borobia, M., Barros, N.B., Marques, F., Trujillo, F. and Flores, P.A.C. (Eds), Book of Abstracts, Workshop on Research and Conservation of the genus Sotalia, 19-23 June 2006, Armação dos Búzios, Rio de Janeiro, Brazil. Latin American Journal of Aquatic Mammals 8(1-2) (supplement). http://dx.doi.org/10.5597/lajam00147.a037.

${ }^{8}$ ReIs, M.S.S., ReIS, LW.D., LimA, F., BARACHO, C. AND Jorge, A. (1998) Nota sobre a dieta alimentar do boto Sotalia fluviatilis Gervais, 1853 (Cetacea, Delphinidae) no litoral do estado da Bahia. Page 173 in Abstracts, VIII Reunião de Trabalho de Especialistas em Mamíferos Aquáticos da América do Sul, 25-29 October, Olinda, PE, Brazil.

${ }^{9}$ Marcucci, A., Cremer, M.J. And CorrêA, M.F.M. (2004) Hábito alimentar de Sotalia guianensis (Cetacea-Delphinidae) e Pontoporia blainvillei (Cetacea-Pontoporiidae) na costa norte de Santa Catarina, Brasil. Page 128 in Abstracts, XI Reunión de Trabajo de Especialistas en Mamíferos Acuáticos de América del Sur, 11-17 September 2004, Quito, Ecuador.
} 
value, suggesting that this dolphin could have a more specialized diet than an opportunistic one in that area (Oliveira, 2003). However, it is recommended that further studies analyzing a larger number of stomach contents throughout its distribution be carried out focusing on this subject.

Table 1. Fish species consumed by Sotalia guianensis on the Brazilian coast.

\begin{tabular}{|c|c|c|c|}
\hline FISH SPECIES & FAMILY & LOCALITY & REFERENCES* \\
\hline Cynoscion striatus & Sciaenidae & SE and S Brazil & 2,4 \\
\hline Cynoscion jamaicensis & Sciaenidae & SE and S Brazil & $2,3,4,11,13$ \\
\hline Cynoscion acoupa & Sciaenidae & SE and S Brazil & $3,7,8,13$ \\
\hline Cynoscion leiarchus & Sciaenidae & SE and S Brazil & $7,8,11$ \\
\hline Cynoscion virescens & Sciaenidae & SE Brazil & 3,11 \\
\hline Cynoscion sp. & Sciaenidae & SE Brazil & 2,6 \\
\hline Micropogonias furnieri & Sciaenidae & SE and S Brazil & $2,3,4,6,8,11,12,13$ \\
\hline Stellifer rastrifer & Sciaenidae & SE and S Brazil & $3,8,11,13$ \\
\hline Stellifer brasiliensis & Sciaenidae & SE and S Brazil & $3,7,8,11$ \\
\hline Stellifer sp. & Sciaenidae & SE and S Brazil & $2,3,6,7,8,11,12,13$ \\
\hline Larimus breviceps & Sciaenidae & SE and S Brazil & $7,8,11,12$ \\
\hline Isopisthus parvipinnis & Sciaenidae & SE and S Brazil & $3,6,8,11,12,13$ \\
\hline Paralonchurus brasiliensis & Sciaenidae & SE and S Brazil & $3,4,8,11,13$ \\
\hline Umbrina canosai & Sciaenidae & SE Brazil & 3 \\
\hline Umbrina coroides & Sciaenidae & SE Brazil & 2 \\
\hline Umbrina sp. & Sciaenidae & SE and S Brazil & 6,8 \\
\hline Menticirrhus americanus & Sciaenidae & SE and S Brazil & $3,4,8,13$ \\
\hline Menticirrhus sp. & Sciaenidae & SE Brazil & 6 \\
\hline Bairdiella rhochus & Sciaenidae & NE Brazil & 10,13 \\
\hline Pogonias chromis & Sciaenidae & SE and S Brazil & 3,8 \\
\hline Nebris microps & Sciaenidae & SE Brazil & 3 \\
\hline Ctenosciaena gracilicirrhus & Sciaenidae & SE and S Brazil & $2,3,6,13$ \\
\hline Macrodon ancylodon & Sciaenidae & SE and S Brazil & $3,7,11$ \\
\hline Diapterus rhombeus & Gerreidae & S Brazil & 8,13 \\
\hline Diapterus olisthostomus & Gerreidae & NE Brazil & 5 \\
\hline Eucinostomus gula & Gerreidae & SE and S Brazil & 8,12 \\
\hline Eucinostomus argentus & Gerreidae & SE and S Brazil & 8,11 \\
\hline Eucinostomus melanopterus & Gerreidae & S Brazil & 8 \\
\hline Eucinostomus sp. & Gerreidae & S Brazil & 13 \\
\hline Gerres sp. & Gerreidae & NE Brazil & 10 \\
\hline Mugil curema & Mugilidae & SE and S Brazil & 4,12 \\
\hline Mugil liza & Mugilidae & SE Brazil & 6 \\
\hline Mugil brasiliensis & Mugilidae & SE Brazil & 2 \\
\hline Mugil sp. & Mugilidae & SE and S Brazil & $3,7,8,9,11,12$ \\
\hline Lycengraulis grossidens & Engraulidae & S Brazil & $4,8,13$ \\
\hline Anchoa tricolor & Engraulidae & S Brazil & 8 \\
\hline Anchoviella lepidentostole & Engraulidae & S Brazil & 8 \\
\hline Anchoa filifera & Engraulidae & SE and S Brazil & 3,7 \\
\hline Anchoa sp. & Engraulidae & SE and S Brazil & $6,8,11,13$ \\
\hline Cetengraulis edentulus & Engraulidae & S Brazil & 7,13 \\
\hline
\end{tabular}


conclusion

\begin{tabular}{|c|c|c|c|}
\hline FISH SPECIES & FAMILY & LOCALITY & REFERENCES* \\
\hline Harengula clupeola & Clupeidae & SE and S Brazil & 12 \\
\hline Odontognathus mucronatus & Clupeidae & SE Brazil & 3 \\
\hline Sardinella brasiliensis & Clupeidae & SE and S Brazil & $3,8,9,13$ \\
\hline Pellona harroweri & Clupeidae & SE and S Brazil & $2,3,6,8,13$ \\
\hline Bagre bagre & Ariidae & SE and S Brazil & 3,12 \\
\hline Sciadeichthys luniscutis & Ariidae & SE Brazil & 3 \\
\hline Arius spixii & Ariidae & SE Brazil & 3 \\
\hline Urophicys brasiliensis & Gadidae & SE and S Brazil & 3,13 \\
\hline Pomatomus saltator & Pomatomidae & SE Brazil & 3,6 \\
\hline Lutjanus griseus & Lujtanidae & S Brazil & 13 \\
\hline Lujtanus sp. & Lujtanidae & SE Brazil & 3 \\
\hline Ariosoma opisthophthalma & Congridae & SE Brazil & 3 \\
\hline Haemulon steidachneri & Haemulidae & SE and S Brazil & 12,13 \\
\hline Genyatremus luteus & Haemulidae & S Brazil & 8,13 \\
\hline Orthopristis sp. & Haemulidae & SE Brazil & 6 \\
\hline Orthopristis ruber & Haemulidae & SE and S Brazil & $3,11,13$ \\
\hline Conodon nobilis & Haemulidae & SE and S Brazil & $3,6,7$ \\
\hline Pomadasys corvinaeformis & Haemulidae & NE, SE and S Brazil & $5,11,13$ \\
\hline Centropomus undecimalis & Centropomidae & SE and S Brazil & 2,8 \\
\hline Trichiurus lepturus & Trichiuridae & NE, SE and S Brazil & $2,3,4,6,8,9,10,11,12,13$ \\
\hline Porichthys porosissimus & Batrachoididae & SE and S Brazil & $2,3,6,8,9,11,12,13$ \\
\hline Ophichthus gomesii & Ophichthiidae & S Brazil & 8,9 \\
\hline Myrophis punctatus & Ophichthiidae & SE and S Brazil & 2,13 \\
\hline Myrichthys ocellacus & Ophichthiidae & NE Brazil & 5 \\
\hline Dules auriga & Serranidae & SE and S Brazil & 12 \\
\hline Citharichthys sp. & Paralichthyidae & S Brazil & 8,13 \\
\hline Paralichthys orbignyanus & Paralichthyidae & SE Brazil & 11 \\
\hline Paralichthys sp. & Paralichthyidae & S Brazil & 13 \\
\hline Achiurus sp. & Achiridae & S Brazil & 8 \\
\hline Peprilus paru & Stromateidae & SE Brazil & 2,3 \\
\hline Dactylopterus volitans & Dactylopteridae & NE Brazil & 5 \\
\hline Pseudupeneus maculatus & Mullidae & NE Brazil & 5 \\
\hline Oligoplites saliens & Carangidae & SE and S Brazil & 12,13 \\
\hline Caranx crysus & Carangidae & SE Brazil & 6 \\
\hline Trachurus lathami & Carangidae & SE Brazil & 6 \\
\hline Romboplites auroirubens & Carangidae & SE Brazil & 6 \\
\hline Selene selapinnis & Carangidae & S Brazil & 13 \\
\hline Chloroscombrus chrysurus & Carangidae & S Brazil & 13 \\
\hline Synodus foetens & Synodontidae & S Brazil & 13 \\
\hline Atherinella brasiliensis & Atherinopsidae & S Brazil & 13 \\
\hline Unidentified & Scaridae & NE Brazil & 5 \\
\hline
\end{tabular}

NE=Northeast Brazil, SE= Southeast Brazil, $S=$ South Brazil. *References: 1) Barbosa and Barros $(2006)^{7}$; 2) Borobia and Barros (1989); 3) Di Beneditto (2000) and Di Beneditto and Siciliano (2007); 4) Emerim (1994); 5) Gurjão et al. (2003); 6) L. Barbosa and N. Barros (pers. comm.); 7) Marcucci et al. $(2004)^{9}$; 8) Oliveira (2003); 9) Oliveira et al. (2008); 10) Reis et al. (1998); ;1) Santos et al. (2002); 12) Schmiegelow (1990); 13) Zanelatto (2001). 
Table 2. Cephalopod and crustacean species consumed by Sotalia guianensis on the Brazilian coast.

\begin{tabular}{llll}
\hline \hline INVERTEBRATE SPECIES & Family & Locality & References* $^{*}$ \\
\hline \hline CEPHALOPODS & & & \\
Loligo plei & Loliginidae & NE, SE and S Brazil & $1,3,4,6,7,8,11$ \\
Loligo sanpaulensis & Loliginidae & SE and S Brazil & $3,6,7,11$ \\
Loligo sp. & Loliginidae & SE Brazil & $1,2,10$ \\
Lolliguncula brevis & Loliginidae & NE, SE and S Brazil & $1,4,6,7,8,9,11$ \\
Octopus sp. & Octopodidae & NE Brazil & 8 \\
Illex argentinus & Ommastrephidae & SE Brazil & 5 \\
Argonauta nodosa & Argonautidae & S Brazil & 11 \\
Unidentified & Sepiolidae & SE Brazil & 2 \\
CRUSTACEANS & & & \\
Farfantepenaeus brasiliensis & Penaeidae & SE and S Brazil & $3,4,6$ \\
Farfantepenaeus paulensis & Penaeidae & SE Brazil & 9 \\
Litopenaeus schmitti & Penaeidae & SE Brazil & 9 \\
Xyphopenaeus kroyeri & Penaeidae & SE Brazil & 7,10 \\
\hline \hline
\end{tabular}

NE=Northeast Brazil, SE= Southeast Brazil, $\mathrm{S}=$ South Brazil. *References: 1) Borobia and Barros (1989); 2) Borobia et al. (1990) ${ }^{10}$; 3) Schmiegelow (1990); 4) Oliveira et al. (2008); 5) Geise and Gomes (1992) ${ }^{11}$; 6) Oliveira (2003); 7) Di Beneditto (2000); 8) Gurjão et al. (2003); 9) Santos et al. (2002); 10) L. Barbosa and N. Barros (pers. comm.); 11) Zanelatto (2001).

The fish length eaten by Guiana dolphins varied from 1.2 to $114.6 \mathrm{~cm}$ (Di Beneditto, 2000; Santos et al., 2002; Gurjão et al., 2003; Oliveira, 2003; Oliveira et al., 2008), but the most frequent lengths consumed were between 3.2 to $16.2 \mathrm{~cm}$, suggesting that the species does not compete directly with the fisheries (Di Beneditto, 2000; Santos et al., 2002; Oliveira, 2003). This statement, however, is not shared by Gurjão et al. (2003), who suggested that the Guiana dolphin might compete with the artisanal fisheries on the Ceará coast (northern Brazil), based on the fish families consumed by this dolphin and those which are most commonly captured by the fisheries. The latter authors, however, did not take into consideration the fish length and a more detailed analysis must be carried out before reaching any conclusion on this topic.

In the Amazon, da Silva (1983) identified 27 fish species from 13 families in the stomachs of $S$. fluviatilis (Table 3). Comparing the food habits of $S$. fluviatilis with the sympatric Amazon River dolphin (Inia geoffrensis) in the Brazilian Amazon, da Silva (1986) ${ }^{12}$ suggested that the tucuxi is more specialized in its diet than $I$. geoffrensis. The minimum and maximum body lengths of fish eaten by the tucuxi were $4.7 \mathrm{~cm}$ and $37 \mathrm{~cm}$, respectively. The feeding behavior described by da Silva (1986) ${ }^{12}$ for the tucuxi in the central Amazon is similar to that observed by Monteiro Filho (1995) for the Guiana dolphin on the southern Brazilian coast. According to these authors, both species usually prey on fish schools (although not exclusively) and use similar fishing strategies. However, due to the completely different ecosystems used by S. guianensis and S. fluviatilis, prey species consumed by these dolphins are also different.

The nutritional composition of milk from an 11yr old $S$. guianensis female, which was incidentally caught in a fishing net together with its 5 mo old calf, was, for protein, $9.5 \mathrm{~g} / 100 \mathrm{~g}$; for fat, $17.1 \mathrm{~g} / 100 \mathrm{~g}$; for $\mathrm{Na}, 148.3 \mathrm{mg} / 100 \mathrm{~g}$; for $\mathrm{K}, 129.1 \mathrm{mg} / 100 \mathrm{~g}$; for $\mathrm{Ca}, 48.8 \mathrm{mg} / 100 \mathrm{~g}$; for $\mathrm{Mg}$, $8.1 \mathrm{mg} /$ $100 \mathrm{~g}$; for $\mathrm{Zn}, 1.03 \mathrm{mg} / 100 \mathrm{~g}$; and for P, $98.0 \mathrm{mg} / 100 \mathrm{~g}$. The Fe concentration was lower than the resolution of the method $(<0.5 \mathrm{mg} / 100 \mathrm{~g})$ (Rosas and Monteiro Filho, 2002).

\footnotetext{
${ }^{10}$ Borobia, M., Barros, N.B., Lodi, L., Capistrano, L., Di Beneditto, A.P., Arruda Ramos, R. and Siciliano, S. (1990) Ecologia alimentar da forma marinha de Sotalia fluviatilis: Uma análise preliminar. Page 10 in Abstracts, IV Reunión de Trabajo de Especialistas en Mamíferos Acuáticos de América del Sur, 12-15 November, Valdivia, Chile.

${ }^{11}$ GeIse, L. And Gomes N. (1992) Ocorrência de plástico no estômago de um golfinho, Sotalia guianensis (Cetacea, Delphinidae). Pages 2628 in Proceedings, III Reunión de Trabajo de Especialistas en Mamíferos Acuáticos de América del Sur, 25-30 July 1988, Montevideo, Uruguay.

12 DA Silva,V.M.F. (1986) Separação ecológica dos golfinhos de água doce da Amazônia. Pages 215-227 in Proceedings I Reunião de Trabalho de Especialistas em Mamíferos Aquáticos da América do Sul. Buenos Aires, Argentina.
} 
Table 3. Fish species consumed by Sotalia fluviatilis in the Amazon basin, according to da Silva (1983).

\begin{tabular}{lll}
\hline \hline FISH SPECIES & FAMILY & LOCALITY \\
\hline \hline Plagioscion sp. & Sciaenidae & Central Amazonia \\
\hline Pachypops sp. & Sciaenidae & Central Amazonia \\
\hline Hypopfthalmus perporosus & Pimelodidae & Central Amazonia \\
Calophysus macropterus & Pimelodidae & Central Amazonia \\
\hline Pimelodus blochii & Pimelodidae & Central Amazonia \\
\hline Pinirampus pinirampu & Pimelodidae & Central Amazonia \\
\hline Ilisha sp. & Pristigasteridae & Central Amazonia \\
\hline Pellona flavipinnis & Pristigasteridae & Central Amazonia \\
\hline Triportheus sp. & Characidae & Central Amazonia \\
\hline Brycon sp. & Characidae & Central Amazonia \\
\hline Curimata ciliata & Curimatidae & Central Amazonia \\
Curimata kneri & Curimatidae & Central Amazonia \\
Curimata laticeps & Curimatidae & Central Amazonia \\
\hline Curimata vittata & Curimatidae & Central Amazonia \\
\hline Curimata latior & Curimatidae & Central Amazonia \\
\hline Curimata sp. & Curimatidae & Central Amazonia \\
\hline Curimatella meyere & Curimatidae & Central Amazonia \\
\hline Eigenmannia melanopogon & Sternopygidae & Central Amazonia \\
\hline Schizodon fasciatus & Anostomidae & Central Amazonia \\
\hline Leporinus fasciatus & Anostomidae & Central Amazonia \\
\hline Mylossoma aureum & Serrasalmidae & Central Amazonia \\
\hline Mylossoma duriventre & Serrasalmidae & Central Amazonia \\
\hline Acarichthys heckelii & Cichlidae & Central Amazonia \\
\hline Hoplias malabaricus & Erythrinidae & Central Amazonia \\
\hline Auchenipterus sp. & Auchenipteridae & Central Amazonia \\
\hline Rhaphiodon vulpinus & Cynodontidae & Central Amazonia \\
\hline Hydrolycus spp. & Cynodontidae & Central Amazonia \\
\hline Prochilodus nigricans & Prochilodontidae & Central Amazonia \\
\hline \hline
\end{tabular}

\section{Reproduction}

Body length at sexual maturity in S. guianensis was estimated to be between $170-180 \mathrm{~cm}$ in males, and 160 $169 \mathrm{~cm}$ in females, and the age of sexual maturity in this dolphin species occurs between 6-7yr in males and 5$7 y r$ in females (Table 4) (Ramos et al., 2000; Rosas and Monteiro Filho, 2002). Sexual maturity in S. fluviatilis is reached at around $140 \mathrm{~cm}$ in males and between 132 and $137 \mathrm{~cm}$ in females (Best and da Silva, 1984). Seasonality in testicular activity was not detected in the Guiana dolphin (Rosas and Monteiro Filho, 2002), while Best and da Silva (1984) mention that adult male tucuxis have seasonally active testes. Adult males of the genus Sotalia have large testes, which can reach up to $3.3 \%$ of the total body weight in S. guianensis (Rosas and Monteiro Filho, 2002 ) and $5 \%$ in active adult males of $S$. fluviatilis (Best and da Silva, 1984). According to Best and da Silva (1984), the tucuxi has a polyandrous mating system with sperm competition, while Rosas and Monteiro Filho (2002) mention a promiscuous mating system in the Guiana dolphin, also with sperm competition. However, considering that polyandry is a very rare mating system among mammals, Rosas and Monteiro Filho (2002) suggested that a promiscuous system with sperm competition may be more likely for both species of the genus Sotalia.

Length at birth of the Guiana dolphin was estimated to be between 92 and $106 \mathrm{~cm}$ and the gestation period can last about one year (Ramos et al., 2000; Rosas and Monteiro Filho, 2002; Santos et al., 2003). On the other hand, Best and da Silva (1984) reported length at birth in $S$. fluviatilis to be around $71-83 \mathrm{~cm}$ and a gestation period of about $10 \mathrm{mo}$. Lactation period was estimated to be between 8.7 to $9.4 \mathrm{mo}$ in the Guiana dolphin (Ramos, 1997; Rosas and Monteiro Filho, 2002) and around $7 \mathrm{mo}$ in the tucuxi (Best and da Silva, 1984). As indicated by ovarian scars, Harrison and Brownell (1971) 
and Best and da Silva (1984), after analyzing the ovaries of 15 females, suggested that ovulation in S. fluviatilis occurs exclusively in the left ovary, while Rosas and Monteiro Filho (2002), after analyzing the ovaries of 23 females, observed that both ovaries are functional in $S$. guianensis. The latter authors, however, mentioned that the left ovary matures earlier than the right one, and the Guiana dolphin can be classified as type II according to the categories described by Ohsumi (1964). Reproductive senescence was observed by Rosas and Monteiro Filho (2002) in ovaries of female S. guianensis older than 25yr. No information is available concerning reproductive senescence in the tucuxi. The main reproductive parameters of the dolphins of the genus Sotalia are presented in Table 4.

The peak of births of Guiana dolphins from the Rio de Janeiro coast occurs in the austral fall (Di Beneditto, 2000), while Rosas and Monteiro Filho (2002) did not record any defined seasonality in the births of this species on the Paraná coast, which is supported by the lack of seasonal testes activities observed in the Guiana dolphin from that region (Rosas and Monteiro Filho, 2002). On the other hand, according to Best and da Silva (1984), births of S. fluviatilis are very seasonal and occur during the low-water period in the Amazon basin, which is well supported by the seasonal testes activity recorded in this species.

\section{Health}

Hematological values described by van Foreest (1980) for the Guiana dolphin and by Mello et al. (2009) for the tucuxi are presented in Table 5. Rosas et al. (2007) presented organ weight data for healthy S. guianensis, which can determine standards for postmortem evaluation and provide physiological information, and can also be used for systematic comparisons. The authors pointed out that they were able to compare only the adrenals, liver, heart, lungs and kidneys with $S$. fluviatilis as those were the only organ weights presented by da Silva and Best (1994) for the tucuxi. Most of the relative organ weights of $S$. guianensis had greater values than those of $S$. fluviatilis, which is probably due to ecological differences in the habitat used by these two dolphin species.

Lobomycosis was reported in Guiana dolphins by de Vries and Laarman (1974). Lobomycosis-like disease and nodular skin disease were reported in S. guianensis inhabiting the biologically and chemically contaminated Paranaguá estuary waters (southern Brazil), but were not recorded in Guiana dolphins living in the cleaner estuary of Cananéia (southeast Brazil), located only $60 \mathrm{~km}$ from the Paranaguá estuary (Van Bressem et al., 2009). These diseases can be caused by organochlorine contaminants, which were not detected in high concentrations in Guiana dolphins from the Cananéia estuary (Yogui et al., 2003). Nevertheless, Guiana dolphins from the Paranaguá estuary presented similar organochlorine values to those reported in dolphins living in very industrialized areas of the northern hemisphere (Kajiwara et al., 2004), which can explain the skin diseases observed by Van Bressem et al. (2009) in dolphins from the estuary of Paranaguá. 'Tattoo lesions' or 'tattoo skin disease' were observed in Guiana dolphins from Baia Norte, Santa Catarina State (southern Brazil) (P. A. Flores, pers. comm.) and Sepetiba Bay, Rio de Janeiro (southeastern Brazil) (Van Bressem et al., 2007). Whitish lesions with a velvety appearance and associated with unrelated wounds, scars and tooth rakes were observed on the back, dorsal fin and flukes of two adult $S$. guianensis from Sepetiba Bay and may be related to poor water quality (Van Bressem et al., 2007). Greenwood and Taylor (1979) reported septicemia in S. guianensis caused by Proteus morgani, Clostridium perfringers, Yersinia enterocolitica, Staphylococcus aureus and

Table 4. Reproductive parameters of Sotalia guianensis and Sotalia fluviatilis, based on Ramos et al. (2000), Rosas and Monteiro Filho (2002), and Best and da Silva (1984).

\begin{tabular}{|c|c|c|c|c|}
\hline \multirow[t]{2}{*}{ PARAMETERS } & \multicolumn{2}{|c|}{ S. guianensis } & \multicolumn{2}{|c|}{ S. fluviatilis } \\
\hline & q & ó & 운 & ó \\
\hline Body size at maturation $(\mathrm{cm})$ & $160-169$ & $170-180$ & $132-137$ & 140 \\
\hline Age at maturation (years) & $5-7$ & $6-7$ & $\mathrm{UN}$ & UN \\
\hline Gestation period (months) & $11-12$ & -- & $\sim 10$ & --- \\
\hline Length of lactation (months) & $8.7-9.4$ & --- & $\sim 7$ & -- \\
\hline Size at birth (cm) & \multicolumn{2}{|c|}{$90-106$} & \multicolumn{2}{|c|}{$71-83$} \\
\hline Ovulation & both ovaries & -- & $\begin{array}{c}\text { left ovary } \\
\text { only }\end{array}$ & -- \\
\hline Fetal growth rate $(\mathrm{cm} / \mathrm{month})$ & & $8.7-9.0$ & & 8.5 \\
\hline Reproductive senescence & yes & -- & UN & -- \\
\hline$\%$ Testes weight/body weight & & up to 3.3 & & up to 5.0 \\
\hline
\end{tabular}


Streptococcus fecalis and a possible case of botulism. Toxoplasmosis was also reported from one animal found dead in Niteroi, Rio de Janeiro State (Bandoli and Oliveira, 1977). Bossenecker (1978) mentioned hepatic degeneration, lung problems and severe vascular thrombosis in Guiana dolphins caught on the Caribbean coast of Colombia. Ruoppolo (2003) mentioned parasitic pneumonia caused by the presence of Halocercus brasiliensis as one of the main causes of mortality of S. guianensis from the coasts of São Paulo and Paraná States (southeast and southern Brazil, respectively) and no pathological lesions caused by gastrointestinal parasites. Marigo et al. (2010) presented a preliminary description of the parasite community and related lesions of specimens of S. guianensis from Paraná and São Paulo States.

The dorsal fin, flippers and flukes of S. guianensis can be severely injured, due to trauma related to net entanglements resulting in partial or complete amputations and deformations. Sometimes remains of nylon gillnets can be found around the body of Guiana dolphins (Azevedo et al., 2009). This constitutes a high percentage of non-lethal entanglements in gillnets that may, however, result in severe injuries and traumas, high stress levels and secondary mortality, which goes unaccounted for $S$. guianensis (Van Bressem et al., 2007).

Osteomyelitis was reported by Furtado and SimõesLopes (1999) in S. guianensis from Santa Catarina coast, in southern Brazil. Osteomyelitis related to periodontal disease was also seen in the right mandible of a $S$. guianensis from Venezuela and possible Crassicauda lesions were also seen in the pterygoids of a mature $S$. guianensis from Rio de Janeiro coast (Van Bressem et al., 2007). Chronic bone lesions, degenerative infections, traumatic bone lesions and developmental bone anomalies in S. guianensis from Rio de Janeiro State were reported by Ramos et al. (2001) and Mendonça de Souza et al. (2006) ${ }^{13}$. On a broader scale, Fragoso et al. (2006) ${ }^{14}$ analyzed the bone pathology of $S$. guianensis deposited in zoological collections in several Brazilian states.

As far as is known, apart from osteomyelitis (Fettuccia et al., 2005) ${ }^{15}$, no other specific disease has been reported for the tucuxi. Spotte (1967) mentioned that a S. fluviatilis caught near Manaus (central Amazonia) by members of the Aquarium of Niagara Falls (USA) died, presumably from shock, and added that this species is very sensitive to handling and subject to fatality from shock. Trujillo et al. (1987) reported a tucuxi with a tripartite tail in the Colombian Amazon, but did not identify the cause of the deformity.

Table 5. Hematological values of Sotalia guianensis and Sotalia fluviatilis. Brazil.

\begin{tabular}{lcccc}
\hline \hline & \multicolumn{2}{c}{$\begin{array}{c}\text { Sotalia guianensis } \\
\text { (Van Foreest, 1980) }\end{array}$} & \multicolumn{2}{c}{$\begin{array}{c}\text { Sotalia fluviatilis } \\
\text { (Mello } \text { et al., 2009) }\end{array}$} \\
& MEAN & RANGE & MEAN & RANGE \\
\hline \hline $\mathrm{Ht}(\%)$ & 40.5 & $38-43$ & 42.5 & $42-43$ \\
$\mathrm{Hb}(\mathrm{g} / \mathrm{dL})$ & 13.4 & $12.9-14.5$ & 15.1 & $14.4-15.8$ \\
$\mathrm{RBC}\left(\mathrm{x} 10^{6} \mathrm{cells} / \mu \mathrm{L}\right)$ & 4.27 & $3.7-5.0$ & 5.6 & $5.2-5.9$ \\
$\mathrm{MCV}(\mathrm{fl})$ & 94 & $86-101$ & 76.5 & $70-83$ \\
$\mathrm{MCH}(\mathrm{pg})$ & 31 & $29-34$ & -- & -- \\
$\mathrm{MCHC}(\mathrm{g} / \mathrm{dL})$ & 33 & $33.7-33.9$ & 35 & $33-37$ \\
$\mathrm{WBC}(\mathrm{cell} / \mu \mathrm{L})$ & 9163 & $5700-14100$ & 13200 & $10800-15600$ \\
\hline \hline
\end{tabular}

\footnotetext{
${ }^{13}$ Mendonça de Souza, S.M.F., LaEta, M., AND Siciliano, S. (2006) Lesões ósseas em colunas vertebrais de golfinhos do gênero Sotalia provenientes do litoral norte do Rio de Janeiro, Brasil. Page 32 in Siciliano, S., Borobia, M., Barros, N.B., Marques, F., Trujillo, F. and Flores, P.A.C. (Eds), Book of Abstracts, Workshop on Research and Conservation of the genus Sotalia, 19-23 June 2006, Armação dos Búzios, Rio de Janeiro, Brazil. Latin American Journal of Aquatic Mammals 8(1-2) (supplement). http://dx.doi.org/10.5597/lajam00147.a022

${ }^{14}$ Fragoso, A. B. L. et al. (2006) Lesões ósseas degenerativas e distribuição etária de exemplares de boto-cinza, Sotalia guianensis, capturados acidentalmente e encalhados na costa brasileira. Page 31 in Siciliano, S., Borobia, M., Barros, N.B., Marques, F., Trujillo, F. and Flores, P.A.C. (Eds), Book of Abstracts, Workshop on Research and Conservation of the genus Sotalia, 19-23 June 2006, Armação dos Búzios, Rio de Janeiro, Brazil. Latin American Journal of Aquatic Mammals 8(1-2) (supplement). http://dx.doi.org/10.5597/lajam00147.a021

${ }^{15}$ Fettuccia, D.C., Da Silva, V.M.F. And SimÕEs-Lopes, P.C. (2005) Presença de costelas cervicais em golfinhos do gênero Sotalia e outras variações morfológicas. Page 86 in Abstracts, III Congresso Brasileiro de Mastozoologia, Aracruz, 12-16 October, Espírito Santo, Brazil.
} 


\section{General Recommendations}

Considering that the amount of natural history information available for the Guiana dolphin is mainly concentrated in the southeastern and southern Brazilian regions, it is recommended to sample the biological parameters from other areas. Therefore, we suggest that studies such as feeding habits, reproduction, age and health, should be carried out, taking into account the different population units identified by genetic analyses (see Cunha et al., 2005; Caballero et al., 2007; Caballero et al., 2010 this volume). Considering these population units, it is recommended that basic biometric data from incidentally caught or stranded dolphins be collected in a standardized way in order to allow comparisons between distinct geographical populations. Special attention should be given to information on S. fluviatilis from the main tributaries of the entire Amazon basin and on S. guianensis from Central America. This procedure would allow reliable comparative studies and identify potential threats to these dolphins throughout their distribution. Fresh carcasses should be weighed whenever possible since the weight/length relationship of specimens can be an indicator of their health (with a good sample size) and can be used as additional information in other analyses, such as contaminant studies. See suggestions of dolphin weighing techniques in Rosas (2000) and Rosas et al. (2007).

Attention should be given to the interpretation of the growth layer groups in teeth when estimating age, especially because $S$. guianensis can present 1 or 2 accessory layers, which can cause significant interference in the reliable age estimation if they are not properly identified as accessory layers. The elaboration of a 'guide' on how to read age in S. fluviatilis should be considered as most of the information concerning age estimation available today is for S. guianensis (see Rosas et al., 2003 and Ramos et al., 2008).

The photo identification catalogues, which already exist for some areas of the Guiana dolphin distribution, should be continuously updated and can be used to estimate vital parameters such as reproductive rate, calving interval, movement patterns and social organization (e.g. Santos and Rosso, 2008). These same catalogues can also be useful to assess some dermal pathologies (such as 'tattoo skin disease') and physical conditions of the dolphins (Van Bressem et al., 2009). Therefore, it is recommended that researchers compare catalogues to look for possible matches among different survey areas.

The recent separation of the two species of the genus Sotalia demands a revision on the conservation status of both species. It seems reasonable to maintain the tucuxi (S. fluviatilis) in the 'Data Deficient' category (IUCN, $2008)^{16}$ due to the uncertainty of some biological parameters of this species and the lack of data quantifying incidental catches and pollution levels affecting this dolphin throughout the whole Amazon region. However, the organochlorine concentrations found in the Guiana dolphins `tissues from the coast of Paraná, Ubatuba and Baixada Paulista (southern Brazil) (Kajiwara et al., 2004; Alonso et al., 2010, this volume) and the hepatic trace elements observed in the livers of dolphins of the same area (Kunito et al., 2004), revealed similar values to those observed in dolphin species of very industrialized areas from the Northern Hemisphere. These, combined with habitat loss and the high incidental catches of Guiana dolphins in fishing nets throughout its distribution (Siciliano, 1994; Di Beneditto et al., 1998; Rosas 2000; Di Beneditto and Rosas, 2008), indicate that S. guianensis is strongly subjected to anthropogenic pressures and its conservation status deserves special attention.

\section{Acknowledgments}

We thank Kesä K. Lehti for the English revision, Marcos César de Oliveira Santos and two anonymous referees provided insightful comments on the manuscript. The organizing committee of the Workshop on Research and Conservation of the Dolphins of the Genus Sotalia, MBR Minerações Reunidas S.A., Cetacean Society International, Humane Society International, US Marine Mammal Commission and Projeto PIATAM Mar (PETROBRAS) provided financial support to cover expenses of the Workshop. Maira Laeta has been supported by Conselho Nacional de Desenvolvimento Científico e Tecnológico (CNPq) and is under the supervision of Sheila Mendonça deSouza, FIOCRUZ/RJ. Fernando C.W. Rosas also thanks $\mathrm{CNPq}$ for financial support.

\section{References}

Alonso, M. B., Marigo, J., Bertozzi, C. P., Santos, M.C., Taniguchi, S. And Montone, R. C. (2010) Occurrence of chlorinated pesticides and polychlorinated biphenyls (PCBs) in Guiana dolphins (Sotalia guianensis) from Ubatuba and Baixada Santista, São Paulo, Brazil. Latin American Journal of Aquatic Mammals 8(1-2): 123-130. http://dx.doi.org/10.5597/ lajam00161

Azevedo, A.F., Lailson-Brito, J., Dorneles, P.R., Van Sluys, M., CunHa, H.A. AND Fragoso, B.L. (2009) Human-induced injuries to marine tucuxis (Sotalia guianensis) (Cetacea: Delphinidae) in Brazil. Marine Biodiversity Records 2: e22. http:/ / dx.doi.org/ $10.1017 /$ S1755267208000262

Bandoli, J.G. and Oliveira, C.A.B. (1977) Toxoplasmose em Sotalia guianensis (van Bénéden, 1863), Cetacea, Delphinidae. Importância Médico-Social. Folha Médica 75: 459-468.

Best, R.C. AND DA SILVA, V.M.F. (1984) Preliminary analysis of reproductive parameters of the bouto, Inia geoffrensis, and the tucuxi, Sotalia fluviatilis, in the Amazon River system. Report

${ }^{16}$ IUCN 2008. 2008 IUCN Red List of Threatened Species. <http://www.iucnredlist.org>. Accessed: 15 February 2008. 
of the International Whaling Commission Special Issue 6: 361-369. Borobia, M. (1984) Comportamento e aspectos biológicos dos botos da Baía de Guanabara, Sotalia sp. B.Sc. Thesis. Universidade Federal do Rio de Janeiro, Rio de Janeiro, Brazil. 81 pp.

Borobia, M. AND BARros, N.B. (1989). Notes on the diet of marine Sotalia fluviatilis. Marine Mammal Science 5(4): 395-399. http:/ / dx.doi.org/10.1111/j.1748-7692.1989.tb00353.x

Bossenecker, P.J. (1978) The capture and care of Sotalia guianensis. Aquatic Mammals 6(1): 13-17.

Caballero, S., Trujillo, F., Vianna, J.A., Barrios-Garrido, H., Montiel, M.G., Beltrán-Pedreros, S., Marmontel, M., Santos, M.C., Rossi-Santos, M., Santos, F.R. and BaKer, C.S. (2007) Taxonomic status of the genus Sotalia: Species level ranking for 'tucuxi' (Sotalia fluviatilis) and 'costero' (Sotalia guianensis) dolphins. Marine Mammal Science 23(2): 358-386. http:/ / dx.doi.org/10.1111/j.1748-7692.2007.00110.x

Caballero, S., Trujillo, F., Vianna, J.A., Barrios-Garrido, H., Montiel, M.G., Beltrán-Pedreros, S., Marmontel, M., Santos, M.C.de O., Rossi-Santos, M., SAntos, F.R. And BAKER, C.S. (2011) Mitochondrial DNA diversity differentiation and phylogeography of the South American coastal and riverine dolphins Sotalia fluviatilis and Sotalia guianensis. Latin American Journal of Aquatic Mammals 8(1-2): 69-79. http://dx.doi.org/10.5597/lajam00155

Carvalho, C.T. (1961) Esboço mastofaunístico do Território do Rio Branco. Revista de Biologia Tropical 9: 1-5.

Carvalho, C.T. (1963) Sobre um boto comum no litoral do Brasil (Cetacea; Delphinidae). Revista Brasileira de Biologia 23: 263-267.

Cunha, H.A., DA Silva, V.M.F., LaILSON-Brito Jr, J., SAntos, M.C.O., Flores, P.A.C., Martin, A.R., Azevedo, A.F., Fragoso, A.B.L., ZaNelatto, R.C. AND Solé-CAVA, A.M. (2005) Riverine and marine ecotypes of Sotalia dolphins are different species. Marine Biology 148(2): 449-457. http://dx.doi.org/10.1007/s00227-005-0078-2

DA SILVA, V.M.F. (1983) Ecologia Alimentar dos Golfinhos da Amazônia. M.Sc. Thesis. Universidade do Amazonas e Instituto Nacional de Pesquisas da Amazônia (INPA). Manaus, Brazil. 110 pp.

DA SILVA, V.M.F. (1994) Aspects of the biology of the Amazonian dolphins genus Inia and Sotalia fluviatilis. Ph.D. Thesis. The University of Cambridge. St. John's College, U.K. 327 pp.

DA SILVA, V.M.F. AND BeST, R.C. (1994) Tucuxi - Sotalia fluviatilis (Gervais, 1853). Pages 43-69 in RIDGWAY, S.H. AND HARRISON, R. (Eds). Handbook of Marine Mammals. Vol. 5. Academic Press, London, U.K.

DA SILVA, V.M.F. AND BEST, R.C. (1996) Tucuxi, Sotalia fluviatilis. Mammalian Species 527: 1-7. http:/ / dx.doi.org/10.2307/3504117

DE VRIES, G.A. And LaARman, J.J. (1974) A case of Lobo's disease in the dolphin Sotalia guianensis. Aquatic Mammals 1: 26-33.

Di BeneditTo, A.P.M. (2000) Ecologia alimentar de Pontoporia blainvillei e Sotalia fluviatilis (Cetacea) na costa norte do Estado do Rio de Janeiro, Brasil. Ph.D. Thesis. Universidade Estadual do Norte Fluminense. Campos dos Goytacazes, RJ, Brazil. 173 pp.

Di Beneditto, A.P.M., Ramos R.M.A. And LimA, N.R.W. (1998) Fishing activity in northern Rio de Janeiro State (Brazil) and its relation with small cetaceans. Brazilian Archives of Biology and Technology 41: 296-302.

Di Beneditto, A.P.M. and Ramos R.M.A. (2004) Biology of the marine tucuxi dolphin (Sotalia fluviatilis) in south-eastern Brazil. Journal of the Marine Biological Association of the United Kingdom 84(6):
1245-1250. http://dx.doi.org/10.1017/S0025315404010744h Di Beneditto, A.P.M. And Rosas, F.C.W. (2008) Mortalidade de Sotalia guianensis. Pages. 219-230 in MonteIRo FILHO, E.L.A. AND MonTEIRO, K.D.K.A. (Eds). Biologia, ecologia e conservação do boto-cinza. Páginas \& Letras Editora e Gráfica, São Paulo, Brazil.

Di Beneditto, A.P.M. AND Siciliano, S. (2007) Stomach contents of the marine tucuxi dolphin (Sotalia guianensis) from Rio de Janeiro, south-eastern Brazil. Journal of the Marine Biological Association of the United Kingdom 87(1): 253-254. http:/ / dx.doi.org/10.1017/S0025315407053647

EMERIM, E.G. (1994) Contribuição para o conhecimento dos hábitos alimentares de delfinídeos (Mammalia, Cetacea, Odontoceti, Delphinidae) nas proximidades da Ilha de Santa Catarina, SC, Brasil. B.Sc. Thesis. Universidade Federal de Santa Catarina, Brasil. 45 pp.

FetTuccia, D.C. (2001) Estudo da variação morfológica e numérica na coluna vertebral do boto-cinza Sotalia fluviatilis guianensis (Van Benéden, 1875) (Cetacea, Delphinidae). B.Sc. Thesis. Universidade Federal de Santa Catarina, Brasil. 63 pp.

Flores, P.A.C., Bazzalo, M., Caballero, S., Santos, M.C.O., RossiSantos, M.R., TrujIllo, F., Bolaños-Jimenez, J., CREMER, M.J., MaYCollado, L.J., Silva, F.J.L., Montiel, M.G., Azevedo, A.F., Meirelles, A.C.O., Flach, L., Barrios, H., SimÕes-Lopes, P.C., CunHa, H.A. and van Waerebeek, K. (2010) Proposed English common name for the Neotropical delphinid Sotalia guianensis (P.-J. Van Beneden, 1864). Latin American Journal of Aquatic Mammals 8(1-2): 179-181. http:/ /dx.doi.org/10.5597/lajam00167

Furtado, M.H.B.C. ANd SimÕes-Lopes, P.C. (1999) Alterações senil-degenerativas e variações anatômicas na coluna vertebral de pequenos cetáceos. Biotemas 12: 133-147.

GeISE, L. (1984) Distribuição geográfica e estimativa populacional dos botos da Baía de Guanabara, Rio de Janeiro, Sotalia sp. B.Sc. Thesis. Universidade Federal do Rio de Janeiro. Rio de Janeiro, Brazil. 66 pp.

Greenwood, A.G. And Taylor, D.C. (1979) Clinical and pathological findings in dolphins in 1978. Aquatic Mammals 7: 71-74.

Gómez-Salazar, C., M. Portocarrero-Aya, F. Trujillo, S. Caballero, J. Bolaños-Jiménez, V. Utreras, T. McGuire, A. Ferrer-Pérez, M. Pool and E. Aliaga-Rossel (2010) Update on the freshwater distribution of Sotalia in Colombia, Ecuador, Peru, Venezuela and Suriname. Latin American Journal of Aquatic Mammals 8(1-2): 171-178. http://dx.doi.org/10.5597/ lajam00166

Gurjão, L.M., Furtado Neto, M.A.A., Santos, R.A. and Cascon, P. (2003) Feeding habits of marine tucuxi, Sotalia fluviatilis, at Ceará State, northeastern Brazil. Latin American Journal of Aquatic Mammals 2(2): 117-122. http:/ / dx.doi.org/10.5597/lajam00040

Harrison, R.J. AND Brownell, R.L. (1971) The gonads of the South American dolphins, Inia geoffrensis, Pontoporia blainvillei, and Sotalia fluviatilis. Journal of Mammalogy 52: 413-419. http:/ / dx.doi.org/10.2307/1378683

Hohn, A.A., Scott, M.D., Wells, R.S., Sweeney, J.C. And Irvine, A.B. (1989) Growth layers in teeth from known-age, freeranging bottlenose dolphins. Marine Mammal Science 5(4): 315342. http://dx.doi.org/10.1111/j.1748-7692.1989.tb00346.x

Kajiwara, N., Matsuoka, S., Iwata, H., Tanabe, S., Rosas, F.C.W., Fillmann, G. and Readman, J.W. (2004) Contamination by persistent organochlorines in cetaceans stranded along 
Brazilian coastal waters. Archives of Environmental Contamination and Toxicology 46(1): 124-134. http:/ / dx.doi.org/ $10.1007 / \mathrm{s} 00244-003-2239-\mathrm{y}$

Krebs, C.J. (1989) Ecological Methodology. Harper Collins Publishers, New York, NY, USA. 654 pp.

Kunito, T., Nakamura, S., Ikemoto, T., Anan, Y., Kubota, R., Tanabe, S., Rosas, F.C.W., Fillmann, G. and Readman, J.W. (2004) Concentration and subcellular distribution of trace elements in liver of small cetaceans incidentally caught along the Brazilian coast. Marine Pollution Bulletin 49(7-8): 574-587. http://dx.doi.org/10.1016/j.marpolbul.2004.03.009

Lins de Almeida, J. (1933) Nouveau nematode parasite de cetacés du Brésil, Halocercus brasiliensis n.sp. Comptes Rendus de la Societe de Biologie 114: 955-958.

Magnusson, W.E., Best, R.C. And Da Silva, V.M.F. (1980) Numbers and behaviour of Amazonian dolphins, Inia geoffrensis and Sotalia fluviatilis, in the Rio Solimões, Brazil. Aquatic Mammals 8: 27-32.

Marigo, J., Ruoppolo, V., Rosas, F.C.W., Valente, A.L., Oliveira, M.R., Dias, R., CATÃo-Dias, J. (2010) Helminths of Sotalia guianensis (Cetacea, Delphinidae) from south and southeastern coasts of Brazil. Journal of Wildlife Diseases 46(2): 599-602.

Mello, D.M.D., Da Silva, V.M.F. and Martin, A.R. (2009) Hematological values of wild tucuxi (Sotalia fluviatilis) from the Central Amazon. Latin American Journal of Aquatic Mammals 7(1-2): 89-91. http://dx.doi.org/10.5597/lajam00141

Monteiro Filho, E.L.A., Monteiro, L.R. And dos Reis, S.F. (2002) Skull shape and size divergence in dolphins of the genus Sotalia: A tridimensional morphometric analysis. Journal of Mammalogy 83(1): 125-134. http:/ / dx.doi.org/10.1644/15451542\%282002\%29083\%3C0125:SSASDI\%3E2.0.CO;2

Monteiro FilHo, E.L.A. (1995) Pesca interativa entro o golfinho Sotalia fluviatilis guianensis e a comunidade pesqueira da região de Cananéia. Boletim do Instituto de Pesca 22: 15-23.

Oliveira, M.R. (2003) Ecologia alimentar de Sotalia guianensis $e$ Pontoporia blainvillei (Cetacea, Delphinidae e Pontoporiidae) no litoral sul do Estado de São Paulo e litoral do Estado do Paraná. M.Sc. Thesis. Universidade Federal do Paraná, Curitiba, Brazil. 79 pp.

Oliveira, M.R., Rosas, F.C.W., Pinheiro, P.C. and Santos, R.A. (2008) Alimentação de Sotalia guianensis. Pages 91-101 in Monteiro Filho, E.L.A. And Monteiro, K.D.K.A. (Eds). Biologia, ecologia e conservação do boto-cinza. Páginas \& Letras Editora e Gráfica, São Paulo, Brazil

OHsumi, S. (1964) Comparison of maturity and accumulation rate of corpora albicantia between the left and right ovaries of Cetacea. Scientific Reports of the Whales Research Institute 18: $123-148$

RAmos, R.M.A. (1997) Determinação de idade e biologia reprodutiva de Pontoporia blainvillei $e$ da forma marinha de Sotalia fluviatilis (Cetacea, Pontoporiidae e Delphinidae) no norte do Rio de Janeiro. M.Sc. Thesis. Universidade Estadual do Norte Fluminense, Campos dos Goytacazes, RJ, Brazil. 95 pp.

Ramos, R.M.A. And Di BeneditTo, A.P.M. (2005) Guia para estudo de cetáceos: métodos para determinação de idade em cetáceos odontocetos. 1.ed. Rio de Janeiro. Universidade Estadual do Norte Fluminense (UENF). Gráfica Luartson do Brasil, v.3, 38 pp.
Ramos, R.M.A., Di BeneditTo, A.P.M. And Lima, N.R.W. (2000) Growth parameters of Pontoporia blainvillei and Sotalia fluviatilis (Cetacea) in northern Rio de Janeiro, Brazil. Aquatic Mammals 26: 65-75.

Ramos, R.M.A., Di BeneditTo, A.P.M. AND SouZA, S.M. (2001) Bone lesions in Sotalia fluviatilis (Cetacea) as a consequence of entanglement: Case report. Brazilian Journal of Veterinary Research and Animal Science 38(4): 192-195. http:/ / dx.doi.org/ 10.1590/S1413-95962001000400009

Ramos, R.M.A., Rosas, F.C.W., Simões-Lopes, P.C., Zanelatto, R.C., DANS, S. AND CRESPO, E.A. (2008) Estimativa de idade em Sotalia guianensis. Pages 193-209 in MonteIro FilHo, E.L.A. AND MonteIRO, K.D.K.A. (Eds). Biologia, ecologia e conservação do botocinza. Páginas \& Letras Editora e Gráfica, São Paulo, Brazil.

Randi, M.A., Rassolin, P., Rosas, F.C.W. and Monteiro Filho, E.L.A. (2008) Padrão de cor da pele em Sotalia guianensis. Pages 11-16 in Monteiro Filho, E.L.A. And Monteiro, K.D.K.A. (Eds). Biologia, ecologia e conservação do boto-cinza. Páginas \& Letras Editora e Gráfica, São Paulo, Brazil

RosAs, F.C.W. (2000) Interações com a pesca, mortalidade, idade, reprodução e crescimento de Sotalia guianensis e Pontoporia blainvillei (Cetacea, Delphinidae e Pontoporiidae) no litoral sul do Estado de São Paulo e litoral do Estado do Paraná, Brasil. Ph.D. Thesis. Universidade Federal do Paraná, Curitiba, Brazil. 145 pp.

Rosas, F.C.W., Oliveira, M.R. and de Mattos, G.E. (2007) Organ weights of Pontoporia blainvillei and Sotalia guianensis (Cetacea: Pontoporiidae: Delphinidae). Journal of the Marine Biological Association of the United Kingdom 87(3): 825-828. http:/ / dx.doi.org/10.1017/S0025315407056470

Rosas, F.C.W., Barreto, A.S. and Monteiro Filho, E.L.A. (2003) Age and growth of Sotalia guianensis (Cetacea, Delphinidae) on the coast of Paraná State, southern Brazil. Fishery Bulletin 101(2): 377-383.

Rosas, F.C.W. And Monteiro Filho, E.L.A. (2002) Reproduction of Sotalia guianensis on the coast of Paraná, southern Brazil. Journal of Mammalogy 83(2): 507-515. http:/ / dx.doi.org/10.1644/ 1545-1542\%282002\%29083\%3C0507:ROTEDS\%3E2.0.CO;2

Ruoppolo, V. (2003) Patologia comparada de cetáceos e pinípedes. M.Sc. Thesis. Universidade de São Paulo, Departamento de Patologia, São Paulo, Brazil. 116 pp.

SANTOS, M.C.O. AND Rosso, S. (2008) Social organization of marine tucuxi dolphins, Sotalia guianensis in the Cananéia estuary of Southeastern Brazil. Journal of Mammalogy 89(2): 347355. http:/ / dx.doi.org/10.1644/07-MAMM-A-090R2.1

Santos, M.C.O., Rosso, S. And Ramos, R.M.A. (2003) Age estimation of marine tucuxi dolphin (Sotalia fluviatilis) in south-eastern Brazil. Journal of the Marine Biological Association of the United Kingdom 83(1): 233-236. http://dx.doi.org/10.1017/S0025315403007021h

Santos, M.C.O., Rosso, S., Santos, R.A., Lucato, S.H.B. AND BAssoI, M. (2002) Insights on small cetacean feeding habits in southeastern Brazil. Aquatic Mammals 28: 38-45.

Schmiegelow, J.M.M. (1990) Estudo sobre cetáceos odontocetos encontrados em praias da região entre Iguape (SP) e Baía de Paranaguá (PR) $\left(24^{\circ} 42^{\prime} S-25^{\circ} 28^{\prime} S\right)$ com especial referência a Sotalia fluviatilis (Gervais, 1853) (Delphinidae). M.Sc. Thesis. Universidade de São Paulo, Brazil. 149 pp.

Siciliano, S. (1994) Review of small cetaceans and fishery 
interactions in coastal waters of Brazil. Report of the International Whaling Commission 15: 241-250.

Sротте, S.H. (1967) Intergeneric behavior between captive Amazon River dolphins Inia and Sotalia. Underwater 4: 9-13.

Trujillo, F., Obregon, C. And Torres, D.F. (1987) River dolphin with unusual tail. Search, December 1987.

VAN BRESSEM, M.F., SANTOS, M.C.O. AND Oshima, J.E.F. (2009) Skin diseases in Guiana dolphins (Sotalia guianensis) from the Paranaguá estuary, Brazil: A possible indicator of a compromised marine environment. Marine Environment Research 67(2): 63-68. http:/ / dx.doi.org/10.1016/j.marenvres.2008.11.002

Van Bressem, M.F., Van Waerebeek, K., Reyes, J., Félix, F., Echegaray, M., Siciliano, S., Di Beneditto, A.P.M., Flach, L., Viddi, F., Ávila, I.C., Herrera, J.C., Tobón, I.C., Bolaños-Jimenez, J., Moreno, I.B., Ott, P.H., Sanino, G.P., Castineira, E., Montes, D., Crespo, E.A., Flores, P.A.C., HaAse, B., Mendonça de Souza, S.M.F.,
LAETA, M. And Fragoso, A.B.L. (2007) A preliminary overview of skin and skeletal diseases and traumata in small cetaceans from South American waters. Latin American Journal of Aquatic Mammals 6(1): 7-42. http://dx.doi.org/10.5597/lajam00108

VAN ForeEst, A.W. (1980) Haematologic findings in Sotalia fluviatilis guianensis. Aquatic Mammals 8: 15-18.

Yogui, G.T., Santos, M.C.O. and Montone, R.C. (2003) Chlorinated pesticides and polychlorinated biphenyls in marine tucuxi dolphins (Sotalia fluviatilis) from the Cananéia estuary, southeastern Brazil. Science of the Total Environment 312(1-3): 6778. http:/ / dx.doi.org/10.1016/S0048-9697\%2803\%2900198-0

Zanelatto, R.C. (2001) Dieta do boto-cinza, Sotalia fluviatilis (Cetacea, Delphinidae), no complexo estuarino da Baía de Paranaguá e sua relação com a ictiofauna estuarina. M.Sc. Thesis. Universidade Federal do Paraná, Setor de Ciências Agrárias, Curitiba, PR, Brazil. 73 pp. 